\title{
Identifikasi Jamur Pada Pasien Penderita Tuberkulosis Paru di RSUP H. Adam Malik Medan
}

\author{
Dewi Setiyawati, Suryani M.Florence Situmeaang* \\ Jurusan Analis Kesehatan Poltekkes Kemenkes Medan \\ `Email: Situmeang.suryani@gmail.com
}

\begin{abstract}
ABSTRAK
Tuberkulosis paru adalah suatu radang parenkrim paru yang disebabkan oleh bakteri Mycobacterium tuberculosis. Mikosis paru merupakan suatu penyakit yang sering tidak terdiagnosis karena gejala klinis yang khas untuk penyakit ini belum diketahui. Seseorang dengan mikosis paru akan menunjukan gejala yang tidak spesifik berupa batuk kronik yang sering dianggap sebagai gejala Tuberkulosis paru. Penelitian ini bertujuan untuk mengidentifikasi Aspergillus sp pada pasien penderita Tuberkulosis paru di RSUP H. Adam Malik Medan. Jenis penelitian yang digunakan adalah penelitian deskriptif yang akan mendeskripsikan tentang Aspergillus sp pada pasien penderita Tuberkulosis paru di RSUP H. Adam Malik Medan. Populasi penelitian adalah seluruh pasien Tuberkulosis Paru di RSUP H. Adam Malik Medan. Hasil penelitian dari 5 sampel menunjukan bahwa sampel nomor 1 ditemukan Aspergillus fumigatus dan Aspergillus niger, sampel nomor 4 ditemukan Aspergillus flavus, sampel nomor 2,3 dan 5 ditemukan Candida albicans. Berdasarkan hasil penelitian dapat disimpulkan bahwa faktor yang mengakibatkan tumbuhnya jamur adalah dari pemberian Obat Anti Tuberkulosis dalam waktu lama yang hanya menekan bakteri dari Tuberkulosis Paru.
\end{abstract}

\section{Kata kunci : Tuberkulosis paru, Mikosis paru, Aspergillus sp}

\begin{abstract}
Pulmonary tuberculosis's an inflammation of the lung parenchrose caused caused by bacterium Mycobacterium tuberculosis. Pulmonary mycosis's a disease that's often undiagnosed because the typical clinical symptom for this disease're unknown. A person with pulmonary mycosis will show nonspecific symptom of chronic cough which is often regarded as a symptom of pulmonary tuberculosis. The study aims to identify Aspergillus $s p$ in patients with pulmonary tuberculosis in $\mathrm{H}$. Adam Malik Central Public Hospital Medan. Tye type of research used's descriptive research that will describe about Aspergillus sp in patients with pulmonary tuberculosis in $\mathrm{H}$. Adam Malik Central Public Hospital Medan. The population was all patients of Tuberculosis Lung at $\mathrm{H}$. Adam Malik Central Public Hospital. The results of this study from 5 sampel show that sampel number 1 found a Aspergillus fumigatus and Aspergillus niger, sampel number 4 found a Aspergillus flavus, sampels number 2,3 and 5 found a Candida albicans. Based on the results of the study can be conclude that the factors that cause the growth of fungus is from the provision of Anti-Tuberculosis Drugs in a long time that only suppress the bacteria from Pulmonary Tuberculosis.
\end{abstract}

\section{Keywords: Pulmonary Tuberculo, Lung Mycosis, Aspergillus sp}

\section{LATAR BELAKANG}

Penyakit Tuberkulosis Paru yang dengan obat-obatan dapat disembuhkan namun tidak jarang meninggalkan lesi sisa seperti kavitas, fibrosis, destroyed lung dan sebagainya yang merupakan faktor predisposisi terhadap infeksi jamur paru. Pada penderita Tuberkulosis Paru dengan efek anatomi paru disertai pemberian obat anti tuberkulosis dalam waktu lama akan menekan flora normal sehingga pertumbuhan jamur oportunistik tidak terhambat. ${ }^{1}$

Menurut WHO berdasarkan jumlah penduduk Indonesia \pm 250.000 .000 penduduk, setiap tahun ditemukan 1.000 .000 lebih kasus Tuberkulosis Paru dengan angka kematian sebesar 100.000 orang/tahun atau 273 orang/hari. Dengan survei tersebut menempatkan Indonesia pada peringkat kedua dengan kasus Tuberkulosis Paru terbanyak setelah India. $^{2}$

Jamur pathogen merupakan suatu mikroorganisme yang dapat menyebabkan penyakit pada manusia karena jamur tumbuh secara kosmopolit dengan kehidupan manusia baik di tanah maupun di air. Penyakit oleh jmaur terjadi akibat infeksi jamur pada tubuh manusia. Infeksi jamur disebabkan oleh kolonisasi spora jamur di organ atau bagian tertentu pada tubuh. ${ }^{3}$

Infeksi karena jamur disebut dengan mikosis. Mikosis pada sistem pernapasan 
dapat terjadi pada saluran napas atas dan saluran napas bawah. Mikosis yang paling sering ditemukan pada saluran napas bawah adalah Tuberkulosis Paru. ${ }^{4}$

Mikosis paru dapat ditemukan di daerah endemis Amerika, Afrika, Meksiko, Canada dan Australia. Di Indonesia, angka kejadian infeksi jamur pada saluran pernapasan masih belum diketahui. Dalam kehidupan sehari-hari, mikosis paru sering salah diagnosa sebagai Tuberkulosis Paru. Hal ini terjadi karena kurangnya gejala klinis patognomosis dan karakteristik radiologi yang khas untuk penyakit ini serta tidak memadai fasilitas pemeriksaan di laboratorium mikologi. ${ }^{5}$

Tingginya kekerapan Tuberkulosis Paru di Indonesia merupakan salah satu penyebab tingginya infeksi jamur paru di Indonesia walaupun masih relatif jarang bila dibandingkan dengan infeksi bakteri atau virus. Golongan jamur yang sering menyebabkan infeksi oportunistik pada paruparu adalah Aspergillus sp. Aspergillus sp dapat membentuk kolonisasi pada bronkus dan kavitas paru dengan latar belakang penyakit Tuberkulosis Paru. Salah satunya adalah Aspergillus fumigatus yang terbukti menghasilkan endotoksin yang mampu menghemolisa eritrosit manusia dan hewan. Jamur Aspergillus fumigatus ternyata memang merupakan yang paling sering menimbulkan Aspergilosis pada manusia. Jamur Aspergillus lainnya yang menyebabkan Aspergilosis pada manusia adalah Aspergillus niger, Aspergillus flavus dan Aspergillus nidulans.

Menurut jurnal penelitian Melati Dwianugrah Khalik, 2017 frekuensi jamur terduga Tuberkulosis Paru lebih tinggi 83,67\% dibandingkan dengan tidak ditemukannya jamur. Dan menurut jurnal penelitian Isra Thristy dan Yahwardiah Siregar, 2016 presentase jamur Aspergillus $s p$ sebagai penyebab infeksi paru-paru adalah $90 \%{ }^{3}$

Tujuan penelitian adalah untuk mengidentifikasi Aspergillus sp pada pasien penderita Tuberkulosis Paru di RSUP H. Adam Malik.

\section{METODE PENELITIAN}

Jenis penelitian yang digunakan adalah penelitian deskriptif sedangkan Lokasi penelitian ini dilakukan di RSUP H. Adam Malik Medan dan pemeriksaannya dilaksanakan di Laboratorium Patologi Klinik Sub Bagian Laboratorium Mikrobiologi RSUP H. Adam Malik Medan. Penelitian ini dilaksanakan pada bulan April - Juli 2018. Populasi penelitian adalah seluruh pasien TB Paru di Dapertement Pulmonologi RSUP $\mathrm{H}$. Adam Malik Medan. Sampel penelitian adalah seluruh pasien Tuberkulosis Paru yang telah di diagnosa berdasarkan rekam medis BTA 2-3 positif dan telah memakan obat anti tuberkulosis yang direkomendasi oleh Dokter Spesialis Pulmonologi RSUP H. Adam Malik Medan.

\section{Jenis Data dan Metode Penelitian}

Jenis data yang digunakan adalah data primer. Data primer diperoleh dengan melakukan percobaan penelitian pada sampel yang telah ditentukan.

\section{Penelitian}

\section{Pengolahan Sampel}

Yang dilakukan pada hari pertama adalah : Pengambilan Sampel, Pemeriksaan Langsung dengan Larutan $\mathrm{KOH} 10 \%$, dan Pemeriksaan Kultur Jamur.

\section{Pengambilan Sampel}

Sampel yang digunakan adalah sputum pagi dari pasien TB Paru, dengan prosedur pengambilan sebagai berikut :

1. Cuci tangan sebelum mengambil sampel.

2. Gunakan Handscon steril dan masker.

3. Sebelum mengeluarkan sputum, pasien diharuskan untuk berkumur dengan air.

4. Pasien dipersilahkan ke tempat khusus pengambilan sputum.

5. Ambil napas dalam-dalam, kemudian tahan 5 detik. Secara perlahan keluarkan napas. Ambil napas dalam sekali lagi, kemudian batuklah dengan keras sehingga keluar sputum dari mulut.

6. Tampung sputum kedalam bokal / wadah steril, ulangi pengambilan sputum sampai mencapai garis $5 \mathrm{ml}$ pada wadah steril.

7. Pasang tutup wadah dengan kuat agar tidak bocor.

8. Cuci bagian luar wadah, kemudian keringkan.

9. Beri label dan cantumkan tanggal pengambilan sputum pada wadah steril (Authority 2004). ${ }^{6}$

\section{Pemeriksaan Kultur Jamur}

1. Pakailah handscon dan masker untuk menghindari terjadinya kontaminasi.

2. Panaskan seluruh panjang kawat ose di atas lampu spirtus.

3. Ambil sputum di dalam wadah steril menggunakan ose cincin. 
4. Dengan ose yang sudah terdapat sputum, buka penutup petridish dan goreskan mada media Saboraud Dextrose Agar secara zig-zag hingga memenuhi setengah permukaan media agar.

5. Tutup kembali petridish dan panaskan seluruh bagian pinggir petridish diatas lampu spirtus.

6. Panaskan kembali kawar ose diatas lampu spirtus.

7. Masukkan kedalam inkubator $25^{\circ} \mathrm{C}$ selama 7-10 hari.

8. Setiap hari dilihat pertumbuhannya, jika tumbuh

9. dilakukan pengecatan dengan $\mathrm{KOH}$ $10 \%$.

10. Jamur yang tumbuh dibaca baik morfologi koloninya maupun hasil pengecatannya.

11. Bila dalam 10 hari tidak ada pertumbuhan maka dinyatakan tidak ada pertumbuhan.

Pada hari ke-2 sampai hari ke-7 yang dilakukan adalah melihat perkembangan pertumbuhan jamur pada media Saboraud Dextrose Agar jika sampai hari ke-7 terdapat pertumbuhan koloni pada media SDA maka dilakukan pengecatan dengan Larutan $\mathrm{KOH}$ $10 \%$.

Pada hari ke-7 yang dilakukan adalah melakukan pengecatan sediaan dengan larutan $\mathrm{KOH} 10 \%$ yang berasal dari koloni yang tumbuh pada media SDA, setelah Tabel 1. Identifikasi jamur

\begin{tabular}{|l|l|l|l|l|}
\hline No & Kode Sampel & Umur & Sex & Hasil \\
\hline 1 & S1 & 45 & L & Aspergillus fumingatus dan Aspergillus niger \\
\hline 2 & S2 & 52 & L & Candida albicans \\
\hline 3 & S3 & 51 & L & Candida albicans \\
\hline 4 & S4 & 38 & L & Aspergillus flavus \\
\hline 5 & S5 & 23 & L & Candida albicans \\
\hline
\end{tabular}

\section{PEMBAHASAN}

Hasil penelitian di RSUP H. Adam Malik Medan terdapat 5 sampel yang menunjukan bahwa sampel nomor 1 ditemukan Aspergillus fumigatus dan Aspergillus niger, sampel nomor 4 ditemukan Aspergillus flavus, sampel nomor 2,3 dan 5 ditemukan Candida albicans.

Menurut WHO tahun 2015 insiden Tuberkulosis paru meningkat seiring dengan peningkatan usia di Indonesia insiden ini terjadi lebih banyak pada laki-laki dengan rentang usia diatas 50 tahun karena menurunnya ketahanan tubuh pada orangorang berusia lanjut. Faktor lainnya yang mempengaruhi terjadinya Tuberkulosis paru adalah kebiasaan merokok. ${ }^{2}$ dilakukan pengecatan diamati dan di identifikasi secara mikroskopis dibawah mikroskop.

\section{Pengamatan morfologi}

1. Panaskan obyek glass di atas nyala api lampu spirtus untuk menghindari adanya mikroorganisme yang ada sehingga tidak mengacaukan penglihatan.

2. Letakkan $1-2$ tetes larutan $\mathrm{KOH} 10 \%$ $10 \%$ pada gelas obyek.

3. Panaskan ose pada lampu spritus dan lewatkan hingga tangkainya juga untuk sterilisasi.

4. Ambil spesimen di daerah yang mengalami pertumbuhan jamur pada medium sabouroud dextrose agar dengan menggunakan ose cincin.

5. Letakkan spesimen pada obyek glas kemudian diratakan.

6. Tutup dengan deck glass.

7. Kemudian amatilah pada mikroskop untuk identifikasi mikroskopis.

8. Amati dibawah mikroskop tanpa minyak emersi. Pertama dengan perbesaran 10x kemudian 40x. ${ }^{7}$

\section{HASIL}

Hasil penelitian dari 5 sampel menunjukan bahwa sampel nomor 1 ditemukan Aspergillus fumigatus dan Aspergillus niger, sampel nomor 4 ditemukan Aspergillus flavus, kode sampel S2,S3,S5 ditemukan Candida albicans 
Sebagaian besar pasien yang mengalami infeksi oportunistik menderita penyekit yang serius dan mempunyai daya tahan tubuh yang terganggu dan infeksi oportunistik juga dapat diderita oleh individu imunokompeten. Selama infeksi kebanyakan pasien menghasilkan respon imun humoral dan seluler yang signifikan terhadap antigen jamur. ${ }^{9}$

Pada penderita Tuberkulosis Paru dengan defek anatomi paru disertai pemberian obat anti tuberkulosa dalam waktu lama yang akan menekan flora normal sehingga pertumbuhan jamur oportunistik tidak terhambat. Penyakit Tuberkulosis Paru kronik juga merupakan predisposisi terhadap aspergilosis invasif paru. Terinhalasi spora jamur Aspergillus dalam jumlah banyak dapat menimbulkan pneumonitis akut dan kanker paru-paru. ${ }^{10}$

Berdasarkan penelitian yang dilakukan oleh Buthia dan Adhikari, 2014 di RS Rujukan Pusat di Sikkim, India. Buthia dan Adhikari melakukan pemeriksaan pada 200 sampel sputum dari pasien Tuberkulosis paru. Pemeriksaan dilakukan secara mikroskopis dengan $\mathrm{KOH}$ dan kultur. Didapatkan bahwa jamur yang paling banyak ditemukan dari pemeriksaan sputum adalah Aspergillus $s p$ dan Candida sp.

Penemuan jamur pada sputum juga dapat terjadi akibat kontaminasi flora normal rongga mulut pada saat pengambilan sputum. Candida albicans merupakan flora normal rongga mulut, jamur ini dapat ditemukan pada sputum pasien yang tidak mengalami mikosis paru karena pasien tidak melakukan pengambilan sputum secara aseptik. ${ }^{11}$

Aspergillus sp dan Candida sp merupakan jenis jamur oportunistik yang bersifat komensal pada orang-orang immunokompeten namun berpotensi menimbulkan penyakit pada orangorang yang mengalami gangguan kekebalan tubuh. ${ }^{1}$

Aspergillus $s p$ menjadi salah satu jamur yang paling sering ditemukan di isolat saluran napas. Aspergilus $s p$ dapat menimbulkan berbagai reaksi infeksi dan alergi pada pasien dengan keadaan immonocompromised. Angka kejadian penyakit ini meningkat secara signifikan seiring dengan meningkatnya jumlah pasien dengan keadaan sistem imun tubuh yang lemah. ${ }^{12}$

Dari penelitian ini didapatkan data bahwa ditemukan jamur Aspergillus fumigatus dan Aspergillus niger pada sampel no 1, Aspergillus flavus pada sampel no 4 dan Candida albicans pada sampel no 2,3, dan 5 dengan pasien positif Tuberkulosis paru yang diberikan pengobatan Obat Anti Tuberkulosis. Pasien dengan infeksi Tuberkulosis paru rentan menderita infeksi oportunistik seperti mikosis akibat pertahana tubuh yang terganggu. Hal ini perlu mendapat perhatian khusus dari petugas medis karena Tuberkulosis paru yang disertai dengan infeksi oportunistik jamur cenderung bersifat virulen dan lebih fatal. ${ }^{13}$

\section{KESIMPULAN}

Setelah dilakukan penelitian tentang Identifikasi Jamur Pada Pasien Penderita Tuberkulosis Paru Di RSUP H. Adam Malik Medan, maka dapat di peroleh kesimpulan yaitu:

Ditemukannya jamur pada kelima sampel yaitu sampel nomor 1 ditemukan Aspergillus fumigatus dan Aspergillus niger, sampel nomor 4 ditemukan Aspergillus flavus, sampel nomor 2,3, dan 5 ditemukan Candida albicans. Faktor yang mengakibatkan tumbuhnya jamur adalah dari pemberian Obat Anti Tuberkulosis dalam waktu lama yang hanya menekan bakteri dari Tuberkulosis Paru dan terkontaminasi flora normal yang berasal dari rongga mulut pada saat pengambilan sampel yang tidak aseptis.

\section{Saran}

Adapun saran yang dapat peneliti sampaikan adalah :

1. Perlu diperhatikan secara khusus pasien tuberculosis paru dengan infeksi sekunder dari oportunistik jamur karena akan bersifat lebih fatal.

2. Perlu diperhatikan lagi cara pengambilan sputum yang sesuai dengan prosedur oleh petugas kesehatan sehingga memperkecil terjadinya kontaminasi pada sampel dan mempengaruhi hasil dari pemeriksaan.

3. Bagi peneliti selanjutnya disarankan untuk melakukan penelitian lebih lanjut mengenai terapatnya jamur pada sputum berdasarkan gejala klinis pada pasien.

\section{Daftar Pustaka}

1. Sukamto. 2004. Pemeriksaan Jamur bilasan bronkus pada penderita bekas tuberkulosis paru. Medan: Universitas Sumatera Utara Digital Library.

2. WHO. 2015. World Health Organization: Report Tuberculosis. [online] Available at: < www.who.int > [Diakses 26 Oktober 2017].

3. Khalif, Melati Dwianugrah. 2017. Repositari: Prevalensi Penemuan Jamur Pada Sputum terduga 
Tuberkuosis Paru. Padang : Fakultas Kedokteran Universitas Andalas.

4. PMKI. 2011. Tatalaksana Mikosis Sistemik. Jakarta: Balai Penerbit FK UI.

5. T. Buthia and L. Adhikari. 2015. International Journal of Research in Medical Sciences: Pulmonary mycoses among the clinically suspected cases of pulmonary tuberculosis. (hal : 260-268). India: Sikkim.

6. Authority, Oregon Health. 2004. Oregon State Library Digital Collections.

$<$ http://www.oregon.gov/oha/PH/DISE ASESCONDITIONS/COMMUNICABL EDISEASE/TUBERCULOSIS/Docume nts/patiented/sput/sputIND.pdf> Available at : [online]. [Diakses 3 Januari 2018].

7. Nugroho, Waskitho. 2011. Identifikasi Jenis Jamur dan Pola Kepekaannya Pada Pasien Infeksi Saluran Kemih Di Rumah Sakit PKU Muhammadiyah Yogyakarta. Yogyakarta: Universitas Muhammadiyah Yogyakarta.

8. Neyrolles, dkk. 2009. Sexual Inequality In Tuberculosis. Prancis : PloS Medicine. < http://journals.plos.org/plosmedicine/jo urnal.pmed.1000199> Availabe at : [online]. [Diakses 25 Juni 2018]

9. Mitchell G.T. 2007. Mikologi Kedokteran : Mikrobiologi Kedokteran Jawetz, Melnick, \& Adelberg. Alih bahasa: Huriawati Hartanto et al., Editor Retna N.E., et al., Ed. 23. Jakarta : EGC.

10. Bennet W. J. 2010. An Overview of the Genus Aspergillus : Aspergillus Molecular and Genomics. Jepang : Edited by Masayuki Machida and Katsuya Gomi.

11. Anissa, Gisela Haza. 2012. Karakteristik Klinis dan Laboratorium Mikologi Pada Pasien Tersangka Mikosis Paru.

12. Kousha, dkk. 2011. Pulmonary Aspergillosis : A clinical Review, 20(121), pp. 156-174. USA : European Respiratory Review.

13. Yadu R. Nawange, dkk. 2015. Prevalence of Opportunistic Fungal Infection in Patients With Pulmonary Tuberculosis in Madhya Pradesh, Central India. $<$ http://www.microbiozjournals.com/pr evalenceofoppurtunisticfungalinfection s> India : Microbioz Journals. Available at : [online] [Diakses 25 Juni 2018]. 